\title{
REDESCRIPTION OF THE TYPE SPECIES OF \\ MYOPSOCUS, M. UNDUOSUS (HAGEN), AND \\ RESULTING NOMENCLATURAL CHANGES IN GENERA AND SPECIES OF MYOPSOCIDAE (PSOCOPTERA)*
}

\author{
By EdWARd L. MockFord, \\ Department of Biological Sciences \\ Illinois State University, \\ Normal, Illinois 61761
}

The assignment of species to the major genera in the Family Myopsocidae has been hampered by lack of detailed morphological information about the types of these genera. The genera involved are Myopsocus Hagen, Lichenomima Enderlein, Phlotodes Enderlein, and Rhaptoneura Enderlein.

Enderlein's (1910) genera were based entirely on wing venational characters. Some of these have later proven to be variable and of questionable value (Badonnel 1967). Roesler (1944) synonymized Phlotodes and Rhaptoneura at the generic level but maintained them as subgenera. Badonnel (1955) stated that genitalic characters justify the maintenance of Rhaptoneura and Phlotodes as genera but did not show what characters were involved. Smithers (1964) assigned all species which might fall in the genera Myopsocus, Lichenomima, Phlotodes, and Rhaptoneura to Myopsocus until the types could be studied. Badonnel (1967) following Enderlein (1910) and Roesler (1944) assigned to Myopsocus all species with Rs and $M$ joined by a crossvein in the hindwing, thus synonymizing Lichenomima with Myopsocus, and assigned all species in which Rs and $\mathrm{M}$ in the hindwing are fused for a distance to Phlotodes, thus synonymizing Rhaptoneura with Phlotodes.

The present paper reports diagnostic features of the type of Myopsocus unduosus (Hagen), the type species of Myopsocus (Enderlein 1910). Genus Myopsocus is re-diagnosed on the basis of this examination, and an augmented diagnosis of Lichenomima is included. Generic synonymies are revised, and the species now assigned to Myopsocus and Lichenomima are listed.

*Manuscript received by the editor August 15, 1982. 


\section{Myopsocus unduosus (Hagen)}

Psocus unduosus Hagen 1859:201.

Myopsocus unduosus (Hagen) Hagen 1866:210.

Type material and its examination.-Types consist of two males, originally pointed, in the Museum of Comparative Zoology, Cambridge, Massachusetts. Each bears a type label with $\mathrm{MCZ}$ number 10118 and the label "Ceylon, coll. Nietner." I first examined these types in January 1970, ascertained that both are males of the same species, and selected one as lectotype. I then soaked the lectotype off the point, placed it in $80 \%$ ethanol, mounted the right wings on a slide in euparal, and cleared and figured the external genitalia. Early in 1982, I borrowed the wing slide and made figures from it.

Measurements $(\mathrm{mm})$. - Forewing length $=3.94$; hindwing length $=$ 3.22 ; posterior tibial length $=1.72$; least distance between compound eyes $=0.27$; transverse diameter of compound eye $=0.42$.

Color characters. - Forewing (Fig. 1) with fairly distinct, mottled crossband in basal half of wing; a distinct stigmasaum darkly marked in middle; entire margin and most of veins with alternating dark and light marking. Hindwing (Fig. 2) unmarked except for brown clouding at base and along anterior margin and alternating dark and light marking along margin from distal end of $R_{1}$ to distal end of $R_{4+5}$. All femora dark brown with a narrow yellowish-white preapical ring.

Structural characters.-Forewing (Fig. 1) with relatively long Rs-M fusion, short $\mathrm{M}-\mathrm{Cu}_{1}$ fusion. Hindwing with $\mathrm{Rs}-\mathrm{M}$ fusion slightly longer than segment of Rs before it. Hypandrium (Fig. 3) elongate, tapering distally, with slightly bulging, shagreened area on each side at about distal two-thirds of length; distal end on each side with field of heavy setae, each seta tapering toward end and base. Phallosome (Fig. 4) elongate, slender; median style separate from lateral arms at about two-thirds distance from base to tips of arms and extending beyond tips of arms. Epiproct (Fig. 5) semicircular except truncated distally, the distal end beset with minute tubercles. Paraproct (Fig. 6) bearing bluntly rounded distal process; sense cushion with 28 trichobothria, all with basal florets.

\section{Diagnostic Features and Synonymy of Myopsocus Hagen}

Various authors have noted the constancy within and among species of the two character states Rs and $M$ joined by a crossvein 

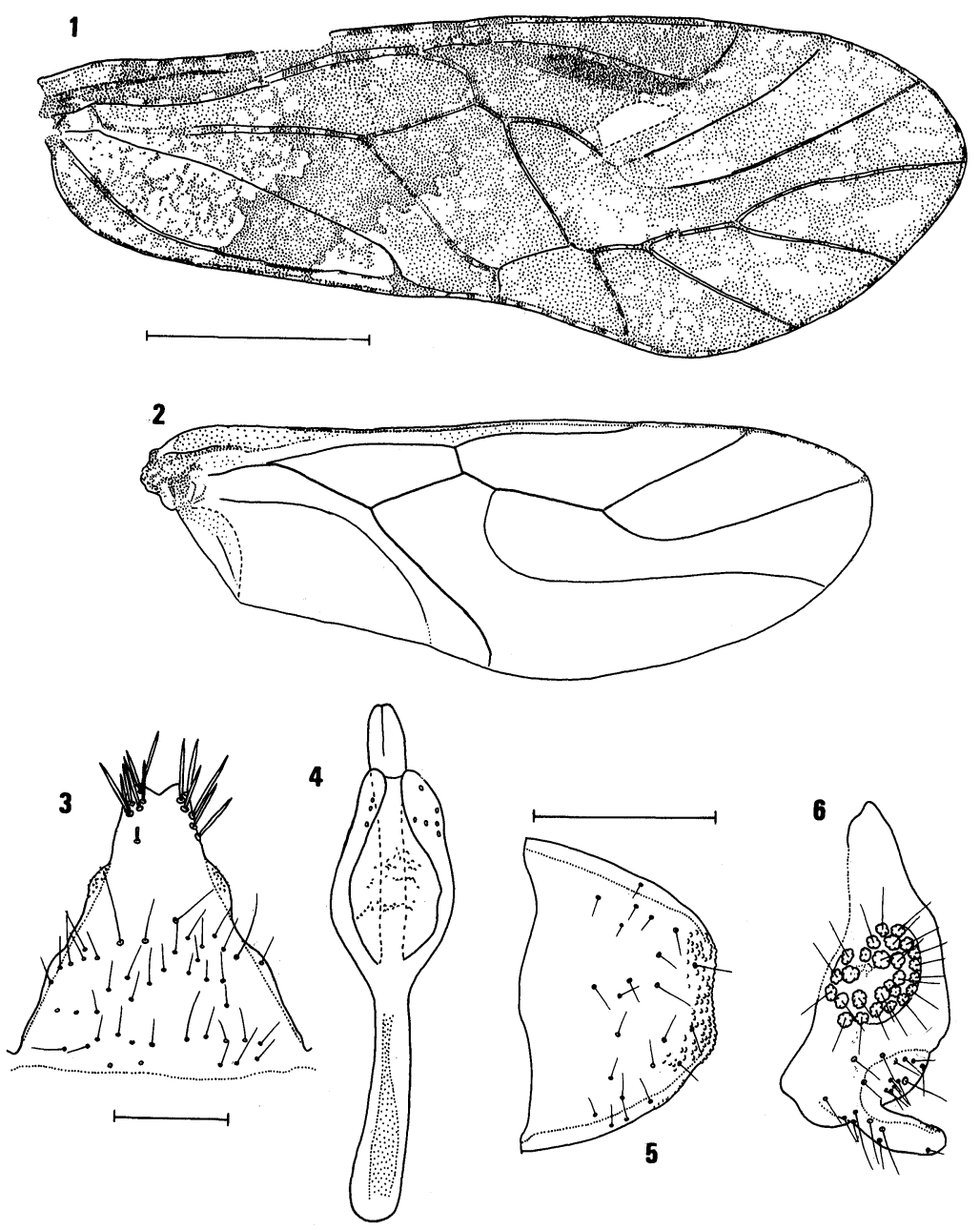

Figs. 1-6. Myopsocus unduosus (Hagen) male lectotype. Fig. 1. Forewing; scale $=1.0 \mathrm{~mm}$. Fig. 2. Hind wing; scale of Fig. 1. Fig. 3. Hypandrium; scale $=0.2$ $\mathrm{mm}$. Fig. 4. Phallosome (dorsal view); scale of Fig. 3. Fig. 5. Epiproct; scale = $0.2 \mathrm{~mm}$. Fig. 6. Right paraproct; scale of Fig. 5. 
versus fused for a distance in the hindwing of the Myopsocid genera under consideration. Enderlein (1910:68) stated about M. unduosus: "im Hinterflügel ist der Radialramus und die Media durch eine Querader mit einander verbunden." Obviously, the statement is not correct. Rs and $\mathrm{M}$ are fused for a distance in the hindwing; however, following Enderlein's erroneous statement, Roesler (1944) and Badonnel (1967) mis-assigned these two character states. Thus Lichenomima (Rs and $\mathrm{M}$ joined by a crossvein) was synonymized under Myopsocus and Rhaptoneura (Rs and $\mathrm{M}$ fused for a distance) was synonymized under Phlotodes. On the basis of examination of the type, it is evident that Myopsocus has as synonyms Phlotodes and Rhaptoneura. Lichenomima is probably tenable as a distinct genus.

Characters correlating with the fusion of Rs and $\mathrm{M}$ for a distance in the hindwing are the following: 1) phallosome generally with a median style (known exceptions: $M$. aldabrensis (New), M. minor (New and Thornton), M. pallidus (Smithers), M. speciosus (Smithers), M. splendidus (Badonnel)); 2) female subgenital plate terminating in a process tapered distally and with two large setae at the tip plus smaller setae in some species.

\section{AssignMent of SPECies to M yoPSOCUS}

Given the above definition and synonymies, Myopsocus includes the following species, grouped according to their nomenclatural history:

1) Species originally placed in Psocus and subsequently transferred to Myopsocus:

australis Brauer 1865, Australia, Melanesia

unduosus Hagen 1859, Sri Lanka

2) Species originally assigned to Myopsocus, all subsequently transferred, in effect, to Phlotodes, or Rhaptoneura, or both in sequence:

clunius Thornton, Lee, \& Chui 1972, Micronesia eatoni McLachlan 1880, Europe, North Africa

furcatus Smithers 1964, Australia

griseipennis McLachlan 1866, Australia

hickmani Smithers 1964, Tasmania

incomptus Smithers 1964, Australia

*kolbei Enderlein 1903 (type of Phlotodes), New Guinea 
novaezealandiae Kolbe 1883, New Zealand

palauensis Thornton, Lee, \& Chui 1972, Micronesia

punctatus Thornton, Lee, \& Chui 1972, Micronesia

3) Species originally assigned to Phlotodes:

aenulus Badonnel 1967, Madagascar

aldabrensis New 1977, Aldabra

alticola Thornton 1981, Fiji

ambiguus Badonnel 1967, Madagascar

amicus Thornton 1981a, Tonga

angolensis Badonnel 1955, Angola, Madagascar

anomalus Smithers \& Thornton 1979, Melanesia

antillanus Mockford 1974, Cuba, Hispaniola, Florida

ascoides Thornton 1981, Fiji

bellus Smithers \& Thornton 1974, New Caledonia

bipunctatus Thronton 1981, Fiji

bomasus Smithers \& Thornton 1974, New Guinea

brunneigenus Smithers \& Thornton 1979, Melanesia

clarki Turner 1975, Jamaica

congolensis Badonnel 1949, Zaire

corticosus Smithers 1964a, Madagascar

cubanus Mockford 1974, Cuba

dentatus Smithers \& Thornton 1974, New Guinea

fenestratus Smithers \& Thornton 1974, New Guinea

graptus Thornton 1981, Fiji, Tonga

gregarius Smithers \& Thornton 1979, Melanesia

gressitti Smithers \& Thornton 1974, New Guinea

hoskinsi Smithers \& Thornton 1979, Melanesia

inocellatus Smithers \& Thornton 1974, New Guinea

lichenosus Enderlein 1931, Seychelles, Madagascar

lineatus Smithers \& Thornton 1979, Melanesia

lyriferus Smithers 1964a, Madagascar

maculatus Smithers \& Thornton 1974, New Guinea, Melanesia

marginatus Smithers \& Thornton 1974, New Guinea

megops Smithers \& Thornton 1979, Melanesia

minor New \& Thornton 1975, Brazil

minutus Mockford 1974, Cuba, Mexico

mjöbergi Karny 1925, Sarawak, Borneo

napuka Thornton 1981, Fiji

obscurus Badonnel 1967, Madagascar 
peltatus Smithers \& Thornton 1974, New Guinea pennyi New 1979, Brazil

personatus Badonnel 1967, Madagascar

pilipes Smithers \& Thornton 1974, New Guinea

placidulus Smithers 1975, Australia

platyvalvulus Smithers \& Thornton 1979, Melanesia

preclarus Smithers \& Thornton 1974, New Guinea

punctatoides Thornton 1981, Fiji, Tonga

quadrisetosus Smithers \& Thornton 1974, New Caledonia

rastafari Turner 1975, Jamaica

reptus Thornton 1981, Fiji

rimosus Smithers \& Thornton 1974, New Guinea

samoanus Karny 1932, Samoa

scabiosus Smithers \& Thornton 1974, New Guinea

splendidus Badonnel 1967, Madagascar

thecatus New \& Thornton 1975a, Malay Peninsula

toxeres Smithers \& Thornton 1974, New Guinea

venustus Smithers \& Thornton 1974, New Guinea

vilazi Smithers \& Thornton 1974, New Caledonia

zimmermani Thornton 1981, Fiji

4) Species originally assigned to Rhaptoneura:

africanus Badonnel 1955, Angola

ciliiferus Smithers 1964a, Madagascar

cryptus Smithers 1957, Natal

*dispar Enderlein 1910 (type of Rhaptoneura), Paraguay

magnificus Smithers 1957, South \& East Africa

muscosus Enderlein 1931, Seychelles

pallidus Smithers 1964a, Madagascar

setosus Smithers 1964a, Madagascar

speciosus Smithers 1957a, Madagascar

5) Species incertae sedis, originally assigned to Myopsocus and best left there until they are re-examined:

bakeri Banks 1916, Philippines, Guam

cinereus Navás 1932, Argentina

enderleini Banks 1913, Philippines

fraternus McLachlan 1866, Assam (originally assigned to Psocus)

pluviosus Navás 1934, India

taurus Banks 1941, Santo Domingo 


\section{RELATIONSHIPS OF M YOPSOCUS UNDUOSUS (HAGEN)}

Badonnel (1967) constructed a classification of the species from Madagascar, and Smithers and Thornton (1974) augmented it to include many of the Old World species. M. unduosus, being known only from the male, and presenting such unique male characters as the phallosome with its basal half a simple rod, and the hypandrium with two distal fields of heavy setae, does not seem to fit into any of the groups that have been proposed. Smithers and Thornton (1974) noted that numerous other species could not be placed in their classification due to paucity of information.

\section{Augmented Diagnosis of LiCHENomima Enderlein}

Species assigned to Lichenomima (assigned to Myopsocus by most authors since Badonnel 1967) have veins Rs and M joined by a crossvein in the hindwing. Correlated with this character are absence of a median style of the phallosome (possible exception: $L$. ariasi New) and female subgenital plate distally with a transverse sclerite, more or less separate from the main plate, and never terminating in a single process tapering posteriorly.

Species assignable to Lichenomima appear to be those listed by Smithers (1967) plus the following:

ampla Smithers \& Thornton 1974 (from Myopsocus), New Guinea

ariasi New 1979 (from Myopsocus), Brazil

capeneri Smithers 1973 (from Myopsocus), South Africa

chelata Thornton \& Woo 1973 (from Myopsocus), Galapagos

Islands

clypeofasciata Mockford 1974 (from Myopsocus), Cuba

coloradensis Banks 1907 (from Myopsocus), Colorado

elongata Thornton 1960 (from Myopsocus), Hong Kong

machadoi Badonnel 1977 (from Myopsocus), Angola

medialis Thornton 1981 (from Myopsocus), Fiji

posterior Navás 1927 (from Psocus), Costa Rica

pulchella New \& Thornton 1975 (from Myopsocus), Brazil

sanguensis New 1973 (from Myopsocus), Nepal

varia Navás 1927 (from Amphigerontia), Costa Rica

Note.-Myopsocus medialis Thornton (1981), assignable to Lichenomima on the basis of hindwing venation, appears to be so different in several other features as to merit a distinct genus. 


\section{SUMMARY}

Examination of the type of Myopsocus unduosus (Hagen), the type species of Myopsocus, allows the genera Phlotodes Enderlein and Rhaptoneura Enderlein to be synonymized with Myopsocus. The species now assigned to Myopsocus are listed according to their nomenclatural history. Species assigned to Myopsocus by most recent authors are re-assigned to Lichenomima Enderlein.

\section{ACKNOWLEDGMENTS}

I wish to thank the officers of the Museum of Comparative Zoology, Cambridge, Massachusetts for the privilege of examining the type material of $M$. unduosus.

\section{Literature Cited}

Badonnel, A.

1949. Psocopte $1 / 4$ res de la Cote d'Ivoire. Rev. Fr. Entomol. 16:20-46.

1955. Psocopte $1 / 4$ res de l'Angola. Diamang Pub. Cult. 26:1-267.

1967. Faune de Madagascar XXIII. Insectes Psocopte $1 / 4$ res. Office de la Recherche Scientifique et Technique Outre-Mer, Centre National de la Recherche Scientifique, Paris, pp. 1-237.

1977. Psocopte $1 / 4$ res de l'Angola V. Diamang Pub. Cult. 89: 103-152.

BANKS, N.

1907. New Trichoptera and Psocidae. J. N.Y. Entomol. Soc. 15: 162-166.

1913. On a collection of Neuropteroid insects from the Philippine Islands. Proc. Entomol. Soc. Wash. 15: 170-181.

1916. Neuropteroid insects of the Philippine Islands. Philipp. J. Sci. D11: 195-217, pls. I, II.

1941. New Neuropteroid insects from the Antilles. Mem. Soc. Cubana Hist. Nat. 15: 385-402, pls. 43-45.

Brauer, F.

1865. Neuropteren. Novara-Expedition, Zoologischer Theil. 1: 1-104, pls. I, II.

ENDERLEIN, G.

1903. Die Copeognathen des Indo-Australischen Faunengebietes. Ann. Hist. Nat. Mus. Nat. Hung. 1: 178-344, pls. III-XIV.

1910. Eine Dekade neuer Copeognathengattungen. Sitz. Ges. Naturf. Freunde Berl. 2: 63-77.

1931. Die Copeognathen-Fauna der Seychellen. Trans. Linn. Soc. Lond. 19:207-240, pls. 14-16.

Hagen, H. A.

1859. Synopsis der Neuropteren Ceylons II. Verh. Zool. Bot. Vereins Wien 9: 199-205. 
1866. Psocinorum et Embidinorum Synopsis Synonymica. Verh. Zool. Bot. Vereins Wien 16: 201-222.

KARNY, H. H.

1925. On the Copeognatha from Mt. Murud and Mt. Dulit, Sarawak. Sarawak Mus. J. 3: 63-74.

1932. Psocoptera. Insects of Samoa. Part VII, Fasc. 4: 117-129.

KOLBE, H. J.

1883. Ueber das Genus Myopsocus und dessen Species. Entomol. Nachr. 9: $141-146$.

MCLachlan, R.

1866. New genera and species of Psocidae. Trans. R. Entomol. Soc. Lond. Ser. 3, 5: 345-353.

1880. Notes on the entomology of Portugal II. Pseudo-Neuroptera (in part) \& Neuroptera-Planipennia. Entomol. Mon. Mag. 17: 103-104.

MOCKFORD, E. L.

1974. Records and description of Cuban Psocoptera. Entomol. Am. 48: 103-215.

Navás, L.

1927. Communicaciones entomológicas 8. Socópteros del Museo de Hamburgo. Rev. Acad. Cienc. Exactas Fis. Quim. Nat. Zarogoza 11: 37-52.

1932. Insectos de la Argentina y Chile. Rev. Soc. Entomol. Argent. 5: 80-82.

1934. Insectos Suramericanos. Rev. Acad. Cienc. Madrid 31: 155-184.

NEw, T. R.

1973. Some Psocoptera from Nepal. Orient. Insects 7: 1-10.

1977. Psocoptera from Aldabra and the Chagos Archipelago. Orient. Insects 11: $89-112$.

1979. New and little-known Psocoptera from the Reserva Ducke, Amazonas. Acta Amazonica 9: 773-781.

New, T. R. AND I. W. B. ThORNTON

1975. Psocomorpha (Psocoptera) collected on recent expeditions to South America. J. Entomol. Ser. B, 44: 27-80.

1975a. Psocomorpha (Psocoptera) from the Malayan Peninsula. Orient. Insects 9: $375-418$.

ROESLER, R.

1944. Die Gattungen der Copeognathen. Stett. Entomol. Zeit. 105: 117-166.

SMithers, C. N.

1957. Three new species of Myopsocidae (Psocoptera) from Natal. Proc. R. Entomol. Soc. Lond. Ser. B, 26: 11-16.

1957a. Notes et descriptions sur les Psocoptères de Madagascar. Naturaliste Malgache 9: 273-280.

1964. The Myopsocidae (Psocoptera) of Australia. Proc. R. Entomol. Soc. Lond. Ser. B, 33: 133-138.

1964a. On the Psocoptera of Madagascar. Rev. Zool. Bot. Afr. 70: 209-294.

1967. A catalogue of the Psocoptera of the world. Aust. Zool. 14: 1-145.

1973. Two new records of Myopsocidae (Psocoptera) from South Africa. J. Entomol. Soc. South. Afr. 36: 131-132. 
1975. Additions to Australian Myopsocidae (Psocoptera). Aust. Entomol. Mag. 2: 51-54.

Smithers, C. N. AND I. W. B. Thornton

1974. The Myopsocidae (Psocoptera) of New Guinea and New Caledonia. Trans. R. Entomol. Soc. Lond. 126: 91-127.

1979. Psilopsocidae and Myopsocidae (Insecta: Psocoptera) of the Bismark Archipelago, Solomon Islands and New Hebrides. Rec. Aust. Mus. 32: 513-545.

Thornton, I. W. B.

1960 New Psocidae and an aberrant new Myopsocid (Psocoptera) from Hong Kong. Trans. R. Entomol. Soc. Lond. 112: 239-261.

1981. Psocoptera of the Fiji Islands. Pac. Insects Monogr. 37: 1-105.

1981a. Psocoptera of the Tongan Archipelago. Pac. Insects Monogr. 37: 106-135.

Thornton, I. W. B., S. S. Lee, And W. D. Chui

1972. Insects of Micronesia: Psocoptera. Insects of Micronesia 8(4): 45-144.

TURNER, B. D.

1975. The Psocoptera of Jamaica. Trans. R. Entomol. Soc. Lond. 126: 533-609. 

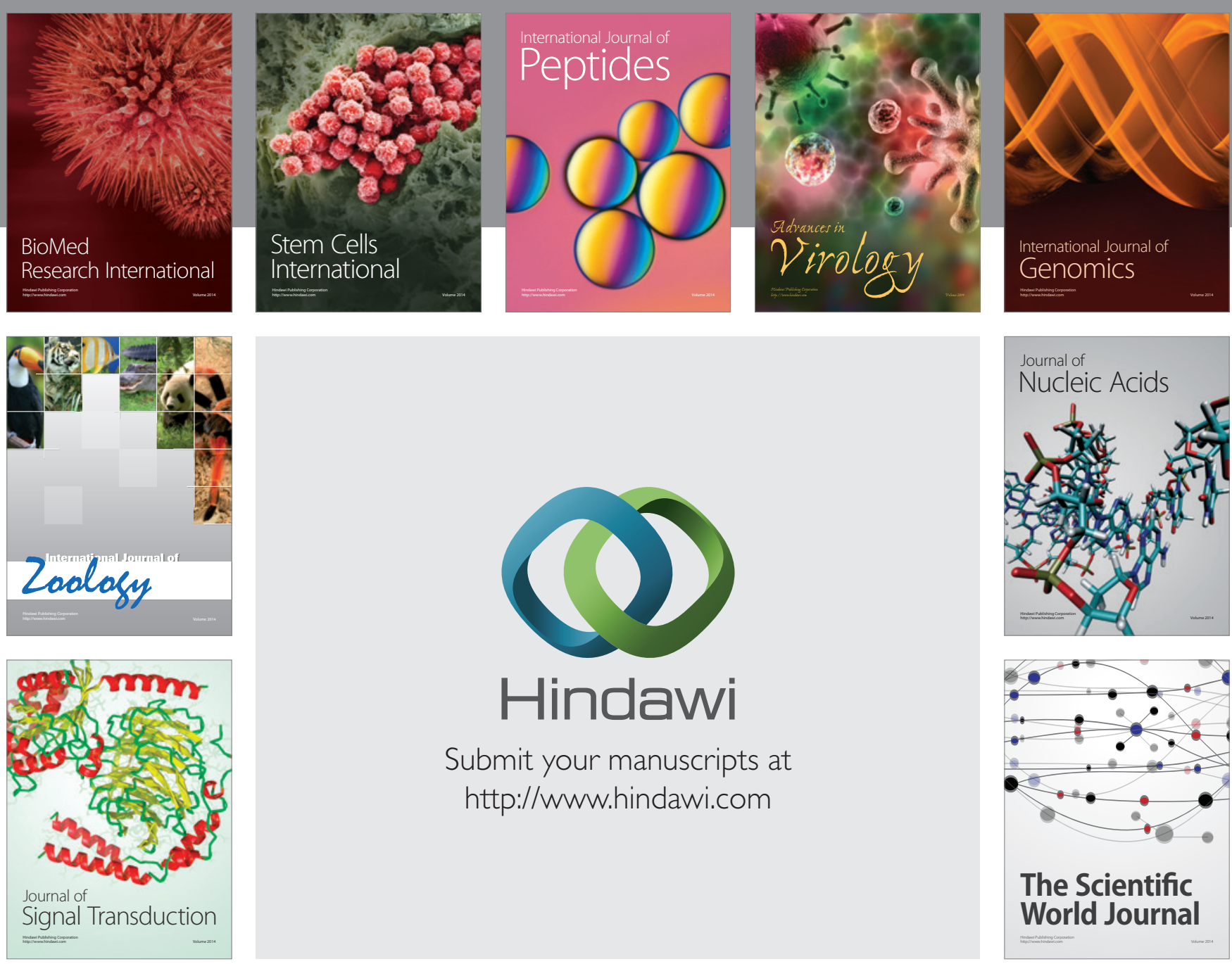

Submit your manuscripts at

http://www.hindawi.com
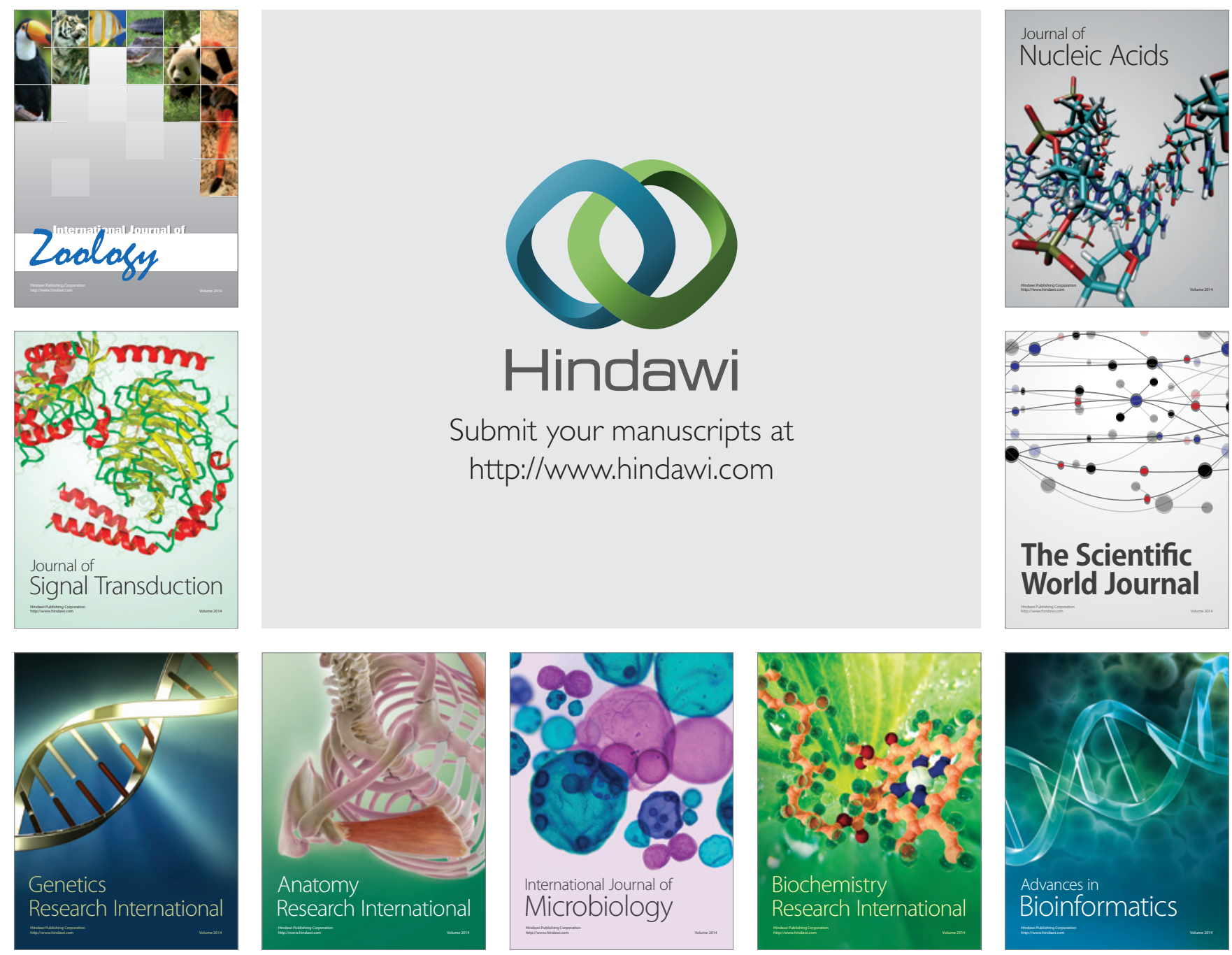

The Scientific World Journal
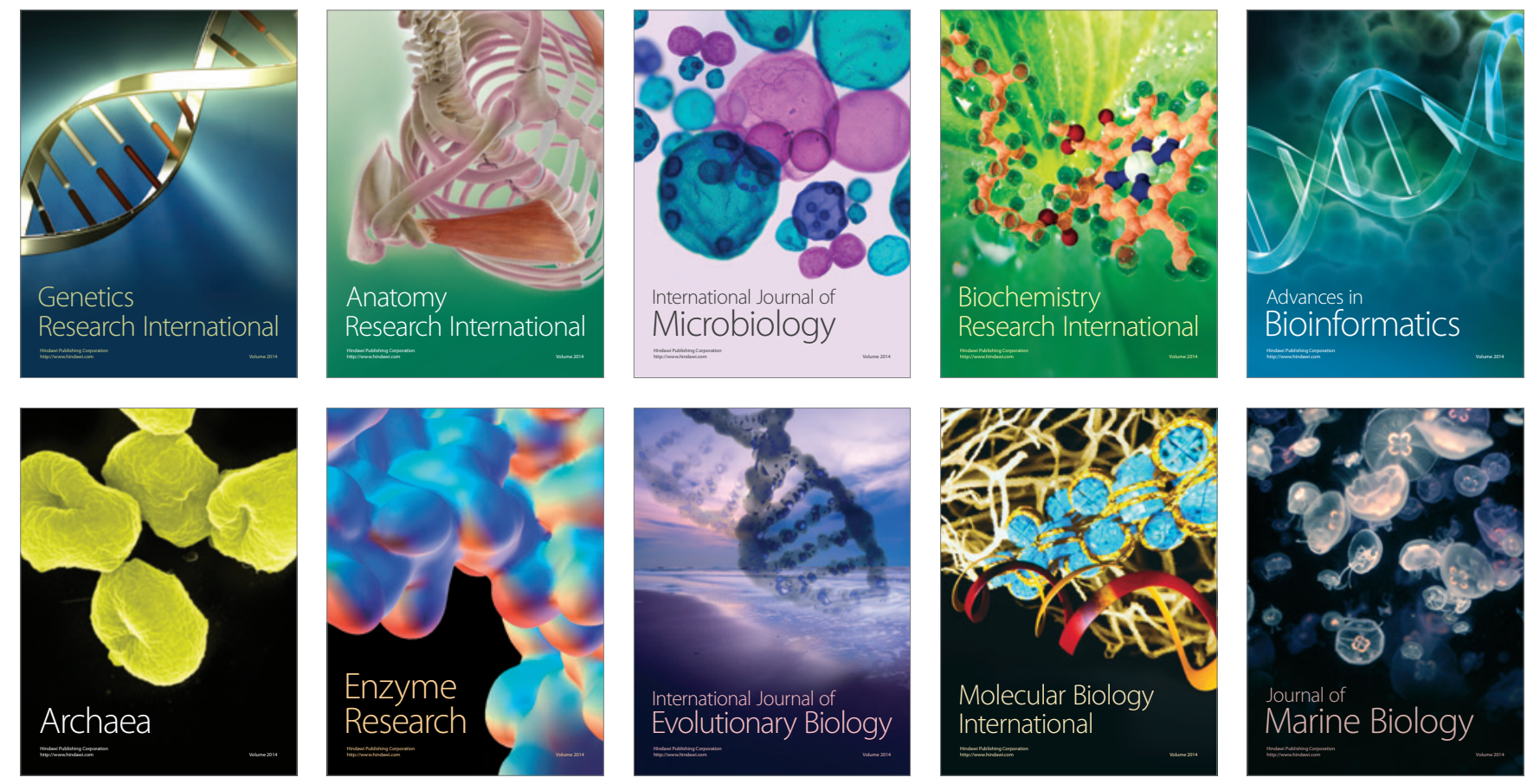